\title{
Pengaruh Kecerdasan Emosional Terhadap Kinerja Karyawan pada Bank Mandiri Cabang Bone
}

\author{
Andi Irfan', \\ Andi Irwan', \\ Andi Alim ${ }^{3}$ \\ ${ }^{1}$ Prodi Manajemen, Sekolah Tinggi Ilmu Manajemen-Lembaga Pendidikan Indonesia, Makassar; \\ Email: andiirfan@stim-lpi.ac.id \\ ${ }^{2}$ Prodi Manajemen, Sekolah Tinggi Ilmu Manajemen-Lembaga Pendidikan Indonesia, Makassar; \\ Email: andirwan261@gmail.com \\ ${ }^{3}$ Alumni Prodi Manajemen, Sekolah Tinggi Ilmu Manajemen-Lembaga Pendidikan Indonesia, Makassar; \\ Email: andi_alimbagu@yahoo.co.id
}

\begin{abstract}
Keberadaan dan peranan teknologi informasi dalam sistem pendidikan telah membawa era baru perkembangan dan menciptakan model baru di tempat kerja maupun di dunia pendidikan. Perubahan ini akan menuntut sumber daya manusia atau karyawan untuk segera menyesuaikan dengan perubahan terebut. Penelitian ini bertujuan untuk melihat pengaruh kecerdasan emosional terhadap kinerja karyawan pada Bank Mandiri Cabang Bone. Metodologi penelitian yang digunakan pada penelitian ini adalah kuantitatif dengan pendekatan analitik regresi linear sederhana. Hasil penelitian ini menemukan bahwa kecerdasan emosional tidak berpengaruh terhadap kinerja karyawan. Penelitian ini menyarankan agar karyawan tetap tenang dalam situasi apapun yang membuat orang lain emosi, tidak mudah tenggelam dan berlarut - larut, agar pekerjaannya bisa terselesaikan sesuai dengan apa yang diinginkan.
\end{abstract}

Kata Kunci: Kecerdasan Emosional, Kinerja Karyawan, Bank Mandiri

\section{PENDAHULUAN}

Keberadaan dan peranan teknologi informasi dalam sistem pendidikan telah membawa era baru perkembangan dan menciptakan model baru di tempat kerja maupun di dunia pendidikan. Perubahan ini akan menuntut sumber daya manusia atau karyawan untuk segera menyesuaikan dengan perubahan tersebut. Sumber daya manusia adalah aset yang sangat vital bagi maju dan berkembangnya organisasi akibat adanya pertukaran yang terjadi. Organisasi tidak hanya mata mengejar pencapaian kapasitas produksi yang tinggi saja, tetapi juga lebih memperhatikan kinerja dalam proses pencapaiannya, dengan demikian kinerja merupakan suatu kunci bagi setiap individu dan organisasi dalam pencapaian kapasitas produksi. Untuk memajukan bobot karyawan maka perlu memperbaiki metode dan model pembinaan karyawan dan menjamin agar para karyawan dapat melaksanakan tugas dengan baik, tanpa mengalami berbagai gangguan yang dapat membongkar kinerja. Manusia adalah perencana organisasi, karakteristik/determinan organisasi, karena dengan kata lain, tanpa peran aktif dari sumber daya manusia, alat canggih apapun tidak dapat bekerja. Kinerja karyawan yang baik pasti akan menghasilkan karyawan yang baik. Agar dapat memberikan pelayanan yang baik maka kesabaran dan dorongan dari karyawan harus dijaga. Khumaedi (2016) menunjukkan bahwa kinerja merupakan tingkat pengadaan produk untuk mencapai tujuan perusahaan. Manajemen kinerja mengacu pada integritas kegiatan yang dilakukan untuk meningkatkan kinerja perusahaan/organisasi, termasuk kinerja masing-masing individu dan kelompok kerja di perusahaan. Menurut Mangkunegara (2016), kinerja adalah; tingkat dan jumlah pekerjaan yang dihasilkan, yang dapat diperoleh karyawan dengan menyelesaikan tugas sesuai dengan tugas yang diberikan kepadanya.

Purnomo (2016) menunjukkan bahwa kecerdasan tertinggi dapat memberikan kontribusi pada kehidupan pada saat yang bersamaan. $80 \%$ talenta termasuk kecerdasan emosional yang berkaitan dengan kecerdasan. Beberapa orang mengatakan bahwa sains dan pendidikan tidak dapat mengubah kecerdasan. Kecerdasan biasanya sudah bawaan lahir, jadi tidak ada yang bisa kita lakukan kecuali melatih dan mempelajari EQ dan tubuh, sehingga masih ada peluang untuk tumbuh dan berkembang untuk membantu mewujudkan kehidupan kita. Kecerdasan Emosional (Emotional Intelligence) adalah suatu posisi dimana seseorang harus dapat mengontrol dirinya sendiri, memiliki semangat sendiri, emosi dan tetap menanggung tekanan yang ditimbulkan oleh berbagai faktor di lingkungan kerja maupun di luar lingkungan kerja. Tekanan tersebut akan menghasilkan pekerjaan di masa yang akan 
datang yaitu berupa efek negatif. Kinerja akhir karyawan tidak hanya dapat dilihat melalui faktor psikologis, tetapi juga ditentukan melalui faktor emosional. Orang yang bisa memantau emosi dengan baik akan mampu menghasilkan kinerja yang baik, teori ini selaras dengan apa yang dikatakan Fachrur (2019) Kecerdasan emosional menjadi salah satu faktor penting yang memadukan teknologi dan Analisis keterampilan untuk mendapatkan apa yang anda inginkan berdasarkan kinerja. Berdasarkan uraian di atas, dapat disimpulkan bahwa manusia membutuhkan jenis kecerdasan lain, yaitu kecerdasan emosional.

Secara tertentu pemimpin perusahaan sangat menginginkan kecerdasan emosional yang tinggi karena mereka menggantikan organisasi, dan berhubungan dengan orang-orang baik di dalam ataupun di luar organisasi serta berperan penting dalam menciptakan moral dan disiplin Goleman dalam Hariyoga dan Suprianto (2011) menyatakan bahwa kecerdasan emosional adalah kemampuan untuk mempersepsikan dan menjelaskan secara efektif ketika menggunakan kekuatan atau kepekaan emosi sebagai sumber energi, informasi, koneksi, dan pengaruh manusia. Melalui kemampuan di atas, karyawan dapat melihat hal-hal batin, motivasi, kekuatan, kekuatan frustasi, perlawanan terhadap emosi dan kesenangan sementara, serta dapat bersimpati dan bekerja sama dengan orang lain. Kecerdasan ini mendukung karyawan untuk mencapai kinerja yang baik.

Menurut Cooper dan Sawaf dalam Gaffar (2020) emotional inteliligence itu mencakup pengendalian diri, semangat, dan kegigihan serta keahlian untuk mendorong diri sendiri dan bertahan melawan frustasi, kesanggupan untuk melawan dorongan hati dan emosi, serta tidak melebih-lebihkan kesenangan mengatur keadaan hati dan melindungi agar beban stress tidak membekukan kemampuan berfikir, untuk membaca perasaan orang lain (empati) dan berdoa untuk menjaga hubungan sebaikbaiknya, kemampuan untuk menyelesaikan masalah, serta untuk memimpin orang-orang yang dikuasai dorongan hati yang kurang baik untuk mengendalikan diri. Pemimpin yang welas asih akan mampu memahami kebutuhan karyawan dan memberikan umpan balik yang konstruktif (Ryza, 2018). Konsep berbasis nilai yang dikembangkan melalui pembangkitan kecerdasan emosional makna pelatihan, yang menunjukkan bahwa kecerdasan emosional positif bagi keberhasilan kerja seseorang. Program pelatihan merupakan salah satu cara untuk meningkatkan kinerja karyawan dalam berbagai situasi transisi internal dan eksternal. Model dan struktur pelatihan yang benar dan penuh warna akan mampu mengurangi kejenuhan karyawan sehingga kinerja karyawan tetap stabil dan berkualitas

Armansyah (2018) menyatakan bahwa kemampuan kecerdasan emosi adalah memantau dan mengendalikan perasaan sendiri dan keterampilan orang lain, serta dapat menggunakan perasaan tersebut untuk menyatukan pikiran dan perilaku. Oleh karena itu kecerdasan emosi sangat penting untuk keberhasilan pekerjaan dan pencapaian kinerja yang sangat baik. Namun, ketika membandingkan keterampilan teknis, IQ, dan EQ sebagai penentu kinerja luar biasa, EQ di setiap tingkat kantor mungkin dua kali lebih penting dari yang lain.

Bank Mandiri adalah badan usaha milik negara Indonesia yang tebentuk perseroan terbatas dan beranjak di bidang jasa keuangan perbankan. Bank Mandiri merupakan suatu Badan Usaha Milik Negara (BUMN) yang beranjak dalam bagian jasa keuangan perbankan, dan formasi usaha Bank Mandiri adalah Perseroan Terbatas. Bank Mandiri, sebagai pemimpin untuk bank yang mempersiapkan jasa kredit perumahan di Indonesia serta memiliki brand image di masyarakat sebagai bank BUMN yang khusus menyediakan Kredit Pemilikan Rumah (KPR) kini sudah mulai saling menyaingi dengan bank-bank lain yang sudah mulai terjun di kredit pemilikan rumah tersebut, namun dalam hal lainnya bank Mandiri sendiri juga dapat menerima simpan pinjam seperti dalam bank lain sekedar pada fokus pada KPR. Sebagai salah satu bank terbesar di indonesia, bank Mandiri selalu menyediakan pelayanan yang baik kepada nasabahnya. Bagaimana cara agar menjadi bank yang baik, dan stabilitas karyawannya meningkat?

Berdasarkan latar belakang diatas bahwa betapa pentingnya kecerdasan emosi dalam membangun produktivitas, maka peneliti tertarik untuk melakukan penelitian yang berjudul: "Pengaruh Kecerdasan Emosional Terhadap Kinerja Karyawan pada Bank Mandiri cabang Bone".

\section{Rumusan Masalah}

Berdasarkan latar belakang permasalahan yang diatas, maka penulis merumuskan masalah, yaitu apakah kecerdasan emosional berpengaruh terhadap kinerja karyawan pada Bank Mandiri Cabang Bone? 


\section{Tujuan Penelitian}

Berdasarkan rumusan masalah diatas maka tujuan penelitan ini adalah untuk mengetahui pengaruh kecerdasan emosional terhadap kinerja karyawan pada Bank Mandiri Cabang Bone.

\section{TINJAUAN PUSTAKA}

\section{Kecerdasan Emosional}

Menurut Goleman (2004), kata emosi berasal dari bahasa latin Movere yang artinya bergerak atau pindah. Menurut oxford English Dictionar, "emosi" mengacu pada aktivitas atau kebingungan pikiran, perasaan, keinginan, atau aktivitas mental yang kuat atau berlebihan. Emosi mewakili pada perasaan dan pikiran, serta keadaan biologis dan visiologis serta tren gerakan. Emosi dapat diklasifikasikan sebagai kemarahan, kekecewaan, kekuatan, kekhawatiran, rasa malu, dll. Emosi bisa menyebar seperti virus, tapi tidak semua emosi bisa menyebar dengan mudah.

Goleman (2004) menemukan dalam sebuah studi oleh Yale School of Management bahwa dalam kelompok kerja, kesenangan dan kenyamanan mudah atau dapat menyebar, sedangkan emosi sangat mudah tersinggung, dan hampir tidak ada depresi yang menyebar.

Menurut Gorman, menjadi pintar memiliki dua arti. Pertama, kecerdasan emosional meliputi pengendalian diri, antusiasme dan ketekunan, serta kemampuan untuk menginspirasi diri sendiri dan menghilangkan rasa frustasi, mengendalikan impuls dan emosi seseorang, dan tidak memaksakan kemampuan seseorang secara berlebihan. Kemampuan untuk mengendalikan semangat seseorang dan dilindungi. Dengan cara ini, beban stres tidak akan melemah dalam berpikir, menemukan perasaan terdalam (simpati) orang lain, dan berdoa untuk menjaga hubungan sebaik mungkin. Keterampilan menyelesaikan konflik dan memimpin diri sendiri dan lingkungan sekitarnya. Menurut Wibowo (2002), kecerdasan emosi merupakan kecerdasan yang menggunakan emosi sesuai permintaan, dan kemampuan mengendalikan emosi dapat berdampak positif. Kecerdasan emosional dapat membantu membangun hubungan dan membawa kegembiraan dan keamanan. Pendapat tersebut menyatakan bahwa kecerdasan emosional menuntut diri untuk belajar mengakui dan menghargai perasaan diri sendiri dan orang lain dan untuk memahami.

Adapun jumlah teoritikus mengelompokkan emosi dalam beberapa jenis tersebut adalah berikut:1) Kemarahan meliputi kekerasan, kemarahan, kebencian, kemarahan, kejengkelan, kesal, kesal, perselisihan, perilaku kekerasan dan kebencian patologis; 2) Kesedihan meliputi kesedihan, kesedihan, pesimisme, depresi, melankolis, cinta diri, kesepian, penolakan, putus asa, dan apakah menjadi sakit karena depresi berat; 3) Ketakutan meliputi kecemasan, ketakutan, neurotisme, kekhawatiran, kecemasan, ketakutan yang kuat, kewaspadaan, ketidakpuasan, teror, ketakutan, fobia patologis, dan panic; 4) Keinginan meliputi kegembiraan, kebahagiaan, ringan, kemandirian, kegembiraan, kesenangan, kenyamanan, harga diri, kesenangan sensual, kagum, kagum, rasa pencapaian, kegembiraan, luar biasa dan sangat menyenangkan; 5) Cinta termasuk penerimaan persahabatan, kepercayaan, kebaikan, hati, keintiman, dedikasi, rasa hormat, cinta dan cinta. 6) Sengatan listrik meliputi mengi, sengatan listrik, dan pingsan; 7) Kemarahan meliputi penghinaan, kebencian, kebencian, ketidaksukaan, dan muntah; 8) Rasa malu meliputi batin, malu, dendam, penyesalan, penghinaan, rasa malu dan patah hati.

Metode klasifikasi ini tidak menyelesaikan semua masalah tentang bagaimana mengklasifikasikan emosi dan perasaan campur aduk, kesedihan dan ketakutan akan perubahan amarah. Kecerdasan emosional dibutuhkan untuk memerangi berbagai emosi yang disebutkan di atas, termasuk di lingkungan kerja. Karena segala bentuk emosi akan berdampak besar pada pekerjaan atau kinerja karyawan.

Komponen Kecerdasan Emosional berdasarkan dari beberapa ahli diantaranya:1) Menurut Dusek dalam Casmini (2007) berpendapat melalui dua jalan yaitu secara kuantitatif adalah proses belajar untuk membobol masalah yang dapat ditakar dengan tes inteligensi, dan secara kualitatif suatu cara berfikir dalam membentuk konstruk bagaimana menghubungkan dan mengelola informasi dari luar yang disinkronkan dengan dirinya; 2) Gardner dalam Lantieri, Goleman, dan Bannel (2009) Menyatakan bahwa bukan hanya satu jenis kecerdasan yang menyelidik yang penting untuk meraih sukses dalam kehidupan, selain itu ada spektrum kecerdasan yang lebar dengan tujuh varietas yaitu linguistik, matematika/logika, spasial, kinestetik, musik,dan interpersonal. Kecerdasan ini dapat dinamakan oleh Gardner sebagai kecerdasan diri sendiri yang oleh Daniel Goleman disebut sebagai kecerdasan emosional; sedangkan Thordike dalam Goleman, Boyatzis, dan McKee (2002) yaitu kekuatan untuk 
mempererat dan mengatur orang lain agar bertindak bijaksana dalam menjalin hubungan, meliputi kecerdasan interpersonal dan kecerdasan intrapersonal. Kecerdasan interpersonal adalah kecerdasan untuk dapat dipahami orang lain, sedangkan kecerdasan intrapersonal adalah keahlian mengelola diri sendiri (A. P. Mangkunegara, 2002).

\section{Kinerja Karyawan}

Dalam organisasi yaitu kinerja, jika tidak ada kinerja maka seluruh organisasi tidak akan dapat mencapai tujuan. Kinerja perlu dijadikan bahan penilaian bagi pimpinan atau manajer. Dalam kamus besar bahasa Indonesia yang dikutip dan dijelaskan oleh Nawawi (2006), "Kinerja adalah:1) Beberapa prestasi, 2) prestasi, 3) Kemampuan kerja.

Menurut Nawawi (2006), penjelasan lain tentang kinerja adalah apabila suatu produk pekerjaan dapat diselesaikan pada waktu yang tepat atau tidak melebihi batas waktu yang ditentukan maka kinerjanya tinggi. Sedangkan menurut Henry Simamora yang dijelaskan dan diterjemahkan oleh Dina (2008), kinerja karyawan adalah tingkat di mana karyawan memenuhi persyaratan pekerjaannya.

Menurut Hasibuan (2006) kinerja adalah pekerjaan yang dilakukan seseorang ketika melaksanakan tugas yang diberikan kepadanya berdasarkan keterampilan, pengalaman, keseriusan dan waktu. Sedangkan kinerja menurut Prawirosentono (2008), atau kinerja dalam bahasa Inggris, berarti seseorang atau sekelompok orang dalam suatu organisasi dapat mencapai tujuan hukum organisasi sesuai dengan kewenangan dan tanggung jawabnya masing-masing. Bekerja, jangan melanggar hukum, dan patuhi etika.

Dari beberapa definisi diatas dapat ditarik kesimpulan sebagai berikut: kinerja karyawan adalah kemampuan untuk memenuhi persyaratan pekerjaan, dapat menyelesaikan tujuan pekerjaan dalam waktu yang sangat sesuai, atau tidak hanya dapat menyelesaikan tujuan pekerjaan dalam batas waktu yang ditentukan, sehingga tujuan tersebut sejalan dengan tujuan perusahaan. Etika dan standar moral. Maka demikian kinerja karyawan dapat memberikan kontribusi bagi perusahaan tersebut.

Menurut Hasibuan (2016), kinerja adalah salah satu hasil kerja yang dicapai seseorang dalam menjalankan tugas-tugasnya atas kecakapan, usaha dan kesempatan. Berdasarkan paparan diatas kinerja adalah salah satu hasil yang dicapai oleh seseorang dalam melaksanakan tugas-tugas yang didasarkan atas kecakapan, pengalaman dan kesungguhan serta waktu menurut standar dan kriteria yang telah ditetapkan sebelum-sebelumnya. Menurut Wibowo (2010), kinerja ialah melakukan pekerjaan dan hasil yang telah dicapai dari pekerjaan tersebut.

Jadi kesimpulannya kinerja adalah melakukan pekerjaan dan hasil yang telah dicapai dari pekerjaan tersebut yang didasarkan atas kecakapan, pengalaman dan kesungguhan serta waktu yang telah ditentukan sebelumnya.

Karakteristik kinerja orang yang mempunyai kinerja tinggi adalah sebagai berikut: 1) Memiliki tanggung jawab pribadi yang tinggi. 2) Memiliki keberanian dalam mengambil dan menanggung resiko yang dihadapi, 3) Memiliki tujuan yang realistis, 3) Memiliki rencana kerja yang menyeluruh dan berjuang untuk merealisasi tujuan tersebut; 4) Memanfaatkan umpan balik (feedback) yang sangat konkrit dalam setiap kegiatan kerja yang dilakukan; 5) Mencari suatu kesempatan agar dapat merealisasikan rencana yang telah diprogramkan.

Faktor-faktor kinerja karyawan Menurut Hasibuan (2006) kinerja adalah pekerjaan yang dilakukan seseorang ketika melaksanakan tugas yang diberikan kepadanya berdasarkan keterampilan, pengalaman, keseriusan dan waktu.

Sedangkan kinerja menurut Prawirosentono (2008), atau kinerja dalam bahasa Inggris, berarti seseorang atau sekelompok orang dalam suatu organisasi dapat mencapai tujuan hukum organisasi sesuai dengan kewenangan dan tanggung jawabnya masing-masing.

Bekerja, jangan melanggar hukum, dan patuhi etika atau etika dari beberapa definisi diatas dapat ditarik kesimpulan sebagai berikut: kinerja karyawan adalah kemampuan untuk memenuhi persyaratan pekerjaan, dapat menyelesaikan tujuan pekerjaan dalam waktu yang sangat sesuai, atau tidak hanya dapat menyelesaikan tujuan pekerjaan dalam batas waktu yang ditentukan, sehingga tujuan tersebut sejalan dengan tujuan perusahaan. Etika dan standar moral.

Indikator kinerja berguna untuk mengetahui derajat karakteristik kinerja karyawan maka perusahaan harus mengukur kinerja karyawan. Untuk mengukur kinerja karyawan, Anda juga membutuhkan indikator yang terkait dengan kinerja karyawan. Banyak sudut pandang menjelaskan indikator kinerja karyawan. Bernadine mengemukakan dalam Tampi (2014) bahwa kinerja karyawan 
memiliki indikator: 1) Kualitas mengacu pada pencapaian hasil kegiatan ke tingkat mendekati sempurna sesuai dengan cara ideal melakukan suatu kegiatan atau mencapai tujuan kegiatan yang diharapkan;2) Kaulitas adalah bilangan yang merepresentasikan banyaknya unit istilah, yaitu banyaknya siklus aktivitas yang diselesaikan; 3) Pengaturan waktu adalah tingkat kegiatan yang diselesaikan pada waktu awal yang dibutuhkan dari perspektif koordinasi dengan hasil keluaran dan waktu maksimum yang tersedia untuk kegiatan lain; 4) Efektivitas adalah pemanfaatan atau pemanfaatan sumber daya manusia secara maksimal dalam suatu organisasi, dengan tujuan untuk meningkatkan keuntungan atau mengurangi kerugian di semua aspek pemanfaatan sumber daya; 5) Kemandirian adalah sejauh mana seorang karyawan dapat melakukan fungsi pekerjaan tanpa meminta bimbingan dari atasan atau mengharuskannya untuk campur tangan untuk menghindari konsekuensi yang merugikan.

Beban kerja ialah sejumlah proses/kegiatan yang harus diselesaikan oleh seseorang pekerja dalamnya waktu tertentu. Apabila seorang pekerja mampu dalam menyelesaikan dan menyesuaikan diri terhadap sebagian tugas yang telah diberikan, maka dalam hal tersebut tidak menjadi suatu beban kerja. Namun jika suatu pekerjaan tidak berhasil atas tugas dan kegiatannya tersebut menjadi suatu dalam beban kerja.

Ada beberapa kelompok beban kerja dari sebagian sumber buku: 1) Menurut Permendagri (2008), beban kerja adalah besaran pekerjaan yang harus dipikul oleh suatunyajabatan/unit organisasi dan menghasilkan hasil kali antara volume kerja dan norma waktu. 2) Menurut Koontz (1997), beban kerja ialah volume dari beberapa hasil kerja atau catatan tentang hasil pekerjaan yang dapat menunjukkan volume yang dapat dihasilkan oleh sejumlah karyawan dalam suatu sebagian bagian tertentu.

Beban kerja dipengaruhi oleh dua faktor yaitu faktor eksternal dan faktor internal. Menurut penelitian Manuaba (2004), bagian-bagian yang mempengaruhi beban kerja diantaranya faktor eksternal adalah beban dari luar tubuh pekerja, seperti: Pada dasarnya tugas fisik, seperti tempat kerja, tata ruang, tempat kerja, alat dan fasilitas kerja, kondisi kerja, dan tugas psikologis, seperti kompleksitas pekerjaan, tingkat kesulitan, dan tanggung jawab pekerjaan; Organisasi kerja, seperti jam kerja, waktu istirahat, shift, shift malam, sistem penggajian, model struktur organisasi, pemberian tugas dan perizinan; Lingkungan kerja adalah lingkungan kerja fisik, lingkungan kimiawi, lingkungan kerja biologis, dan lingkungan kerja psikologis. Sedangkan faktor internal yaang mempengaruhi beban kerja yaitu faktor dari dalam diri sendiri/dari faktor eksternal akibat respon beban kerja eksternal. Faktor internal tersebut meliputi faktor fisik (jenis kelamin, usia, berat badan, status gizi, dan status kesehatan) dan faktor psikologis (motivasi, persepsi, keyakinan, keinginan, dan kepuasan). Menurut Mangkuprawira (2011) beban kerja dibagi menjadi 3 kondisi yaitu: 1) Beban kerja yang terlalu banyak atau beban kerja yang tinggi akan membuat karyawan merasa lelah, karena terlalu banyak tugas, bahkan menimbulkan tekanan kerja 2) Dalam kondisi yang terlalu rendah, hal ini berarti beban kerja sangat kecil sehingga mengakibatkan banyak karyawan yang tidak dapat berproduksi yang akan mengakibatkan terjadinya in-efisiensi biaya yaitu perusahaan membayar lebih banyak karyawan sedangkan produktivitas tetap tidak berubah; 3) Kondisi ideal adalah pekerjaan memenuhi persyaratan karyawan.

Indikator beban kerja Menurut Putra (2012) dibagi menjadi dua bagian: 1) Tujuan yang ingin dicapai Pandangan pribadi tentang besarnya target pekerjaan yang diberikan untuk penyelesaian pekerjaan yaitu grinding, rolling, packaging dan transportasi. Kemudian Anda bisa melihat hasil pekerjaan yang harus diselesaikan dalam jangka waktu tertentu. 2) Kondisi kerja. Menjelaskan pandangan semua orang tentang kondisi kerja, misalnya membuat keputusan cepat saat menangani barang, dan mengatasi kejadian tak terduga, seperti melakukan pekerjaan ekstra di luar waktu yang dijadwalkan. 3) Gunakan waktu kerja. Waktu yang diperlukan untuk kegiatan yang akan dilakukan berkaitan dengan produksinya (waktu siklus atau waktu standar atau waktu dasar). 4) Standar pekerjaan. Kesan yang dapat dimiliki oleh setiap individu mengenai suatu pekerjaan, contohnya perasaan yang muncul mengenai beban kerja yang harus diselesaikannya dalam jangka waktu tertantu yang telah ditentukan.

\section{Kerangka Fikir}

Dengan berkembangnya tujuan penelitian di atas dan penelitian teoritis maka akan dijelaskan kerangka pemikiran tentang pengaruh kecerdasan emosional terhadap kinerja karyawan PT. Bank Mandiri cabang Bone. Gambar berikut menggambarkan kerangka teoritis penelitian. 


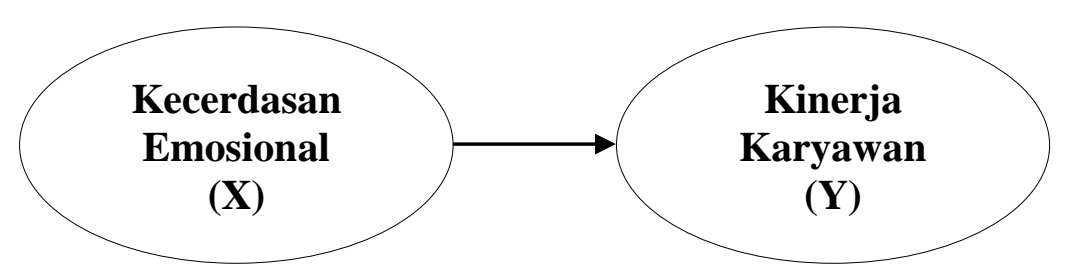

Gambar: Kerangka fikir

Maka lahirnya kecerdasan emosional, terhadap kinerja dalam diri seorang karyawan tentunya tidak berpengaruh dikarenakan dalam bekerja harus fokus dalam suatu pekerjaan tidak oleh menyangkut pautkan dengan urusan keluarga atau apapun itu yang bukan menyangkut dengan pekerjaan. Apabila seluruh karyawan atau sebagian besar karyawan mempunyai kinerja yang tinggi maka efektivitas perusahaan akan meningkat agar bisa menumbuhkan perusahaan menjadi berkembang labih besar dan lebih baik lagi. Maka dengan adanya kinerja yang baik dalam seorang karyawan maka tingkat yang akan dicapai dalam target perusahaan jangka pendek dan Jangka panjang akan lebih terpenuhi.

\section{Hipotesis}

Dengan mengacu pada latar belakang, pertanyaan dan tujuan penelitian yang telah diuraikan, maka hipotesis yang dikemukakan dalam penelitian ini adalah: "Diduga kecerdasan emosional tidak berpengaruh terhadap kinerja karyawan PT. Bank Mandiri cabang Bone.

\section{METODE PENELITIAN \\ Jenis Penelitian}

Jenis penelitian yang digunakan dalam penelitian ini adalah kuantitatif dengan pendekatan analitik regresi liner berganda untuk mengetahui pengaruh hubungan kecerdesan emosional dengan kinerja karyawan pada Bank Mandiri Cabang Bone.

\section{Populasi dan sampel}

Populasi menurut (Sugiyono, 2015) populasi adalah wilayah generalisasi yang terdiri atas obyek atau subyek yang mempunyai kualitas dan karakteristik tertentu yang ditetapkan oleh peneliti untuk dipelajari dan kemudian ditarik kesimpulannya dan yang menjadi populasi adalah seluruh karyawan Bank Mandiri Cabang Bone sejumlah 30 orang.

Sampel merupakan bagian dari ukuran dan karakteristik populasi, kemudian (Sugiyono, 2015) mengusulkan teknik sampling jenuh yang mengambil semua anggota populasi sebagai sampel berdasarkan teknik pengambilan sampel. Saat Anda ingin menggeneralisasi dengan kesalahan kecil, biasanya Anda melakukan ini. Teknik pengambilan sampel dalam penelitian ini adalah total sampling yaitu seluruh karyawan menjadi sampel dalam penelitian ini, yang terdapat sebanyak 30 orang karyawan pada Bank Mandiri cabang Bone.

\section{Jenis dan sumber data}

Jenis data dibagi atas dua bagian yaitu data kuantitatif adalah data dalam bentuk digital atau data kuantitatif yang diperkirakan. Oleh karena itu, data kuantitatif merupakan data yang cenderung dianalisis dengan cara atau teknik statistik. Sedangkan, Data kualitatif adalah data yang berupa kata atau kalimat (Sugiyono, 2015).

Sumber data diantaranya data primer merupakan sumber data yang menyediakan data secara langsung ke pengumpul data dengan menggunakan kuensioner. Sedangkan data sekunder adalah data yang diperoleh dengan membaca, meneliti dan memahami media dari dokumen lain, buku dan dokumen perusahaan.

\section{Teknik pengumpulan data}

Teknik pengumpulan data yang digunakan adalah Penelitian di tempat, yaitu penelitian yang bertujuan untuk memperoleh data secara langsung yang dilakukan pada lembaga penelitian, yaitu data yang diperoleh melalui cara-cara sebagai berikut: 1) Interview (wawancara) adalah teknik pengumpulan data melalui tanya jawab lisan terhadap subjek penelitian yang berkaitan dengan pertanyaan penelitian; 2) Observasi, yaitu teknologi pengumpulan data dengan mengamati langsung objek penelitian. 3) Survei kuesioner dalam penelitian ini dengan mengunakan skala likert yaitu melalui teknik pengumpulan data 
berupa daftar pertanyaan maupun pernyataan yang berkaitan dengan objek penelitian dan responden yang terkait langsung dengan objek penelitian diberikan satu persatu. Sumber indicator penelitian ini diadaptasi dari teori Goleman (2004), Wibowo (2002) dan Putra (2012) dan disesuaikan dengan lingkungan penelitian.

\section{Defenisi Oprasional Varibel Penelitian}

Kecerdasan Emosional dalam penelitian ini adalah kemampuan untuk mempersepsikan dan menjelaskan secara efektif ketika menggunakan kekuatan atau kepekaan emosi sebagai sumber energi, informasi, koneksi, dan pengaruh manusia.

Kinerja Karyawan dalam penelitian ini adalah kemampuan untuk memenuhi persyaratan pekerjaan, dapat menyelesaikan tujuan pekerjaan dalam waktu yang sangat sesuai, atau tidak hanya dapat menyelesaikan tujuan pekerjaan dalam batas waktu yang ditentukan, sehingga tujuan tersebut sejalan dengan tujuan perusahaan.

\section{Teknik Analisis}

Metode analisis yang digunakan dalam penelitian ini dengan menggunakan Regresi Linear Sederhana adalah suatu metode perhitungan untuk mengetahui pengaruh antara independen (X) dan variabel independen (Y). Rumus regresi linear sederhana menurut (Sugiyono, 2015) y $=\mathrm{a}+\mathrm{bx}$. Dimana: $\mathrm{a}=$ Konstanta; $\mathrm{b}=$ Koefisien Regresi; $\mathrm{x}=$ Variabel Dependent (Kinerja Karyawan); $\mathrm{y}=$ Variabel Independen (Kecerdasan Emosional).

Teknik analisis ini dipilih peneliti karena selain untuk mengetahui pengaruh kecerdasan emosional (X) terhadap kinerja karyawan (Y), juga untuk mengetahui seberapa besar pengaruh kecerdasan emosional terhadap kinerja karyawan.

\section{HASIL PENELITIAN \\ Deskriptif Penelitian}

Penelitian ini membahas tentang pengaruh kecerdasan emosional terhadap kinerja karyawan berdasarkan jumlah karyawan di Bank Mandiri Cabang Bone jumlah responden sebanyak 30 orang kemudian ditentukan berdasarkan tingkat pendidikan, jenis kelamin, umur dan jam kerja. Identifikasi ini biasanya dilakukan untuk mengetahui identitas orang yang diwawancarai. Informasi lebih detail mengenai hasil uraian masing-masing karakteristik narasumber dijelaskan sebagai berikut:

Tabel 1. Identitas responden berdasarkan jenis kelamin, Umur dan Jenjang Pendidikan

\begin{tabular}{lcc}
\hline Identitas Responden & Jumlah Karyawan & Persentase (\%) \\
\hline Jenis kelamin & & \\
Laki-laki & 18 & $60 \%$ \\
Perempuan & 12 & $40 \%$ \\
\hline Umur & & \\
$21-30$ & 25 & $83 \%$ \\
$30-45$ & 5 & $17 \%$ \\
\hline Tingkat Pendidikan & & \\
Diploma & 3 & $80 \%$ \\
S1 & 24 & $10 \%$ \\
S2 & 3 & $\mathbf{1 0 0} \%$ \\
\hline Jumlah & $\mathbf{3 0}$ & \\
\hline
\end{tabular}

Sumber: Data Primer 2020

Berdasarkan tabel diatas diketahui bahwa responden dalam penelitian ini sebanyak 30 orang (100\%) yang terdiri dari responden yang berjenis kelamin laki-laki sebanyak 12 orang (40\%) dan responden dengan jenis kelamin perempuan sebanyak 18 orang $(60 \%)$. Sedangkan untuk identitas responden berdasarkan ditemukan umur responden antara 21-30 tahun sebanyak 25 orang dengan persentase $83 \%$ dan umur responden diatas 30 tahun sebanyak 5 responden dengan persentase $17 \%$. Tabel diatas juga memperlihatkn identitas pendidikan responden dengan jenjang pendidikan Diploma sebanyak 3 orang (10\%), Sarjana S1 sebanyak 24 orang (80\%) dan S2 sebanyak 3 orang (10\%).

\section{Uji Validitas dan Reliabilitas}

Uji validitas digunakan untuk mengukur sah atau validnya data penelitian ini, dimana uji korelasi ini digunakan untuk mengetahui adanya pengaruh atau menentukan besarnya koefisien korelasi 
antara dua variable dan Pengujian reliabilitas dilakukan dengan cara menguji coba instrument sekali saja. kemudian dianalisis dengan menggunakan metode alpha cronbach sebagaimana terlihat pada tabel berikut ini:

Tabel 2 Hasil Analisis Uji Validitas dan Reliabilitas Instrumen Angket Kecerdasan Emosional dan Kinerja Karyawan

\begin{tabular}{|c|c|c|c|c|c|}
\hline \multirow{2}{*}{$\begin{array}{l}\text { Variabel } \\
\text { Penelitian }\end{array}$} & \multirow{2}{*}{$\begin{array}{c}\text { Koefesien } \\
\text { Validitas }\end{array}$} & \multirow[b]{2}{*}{ r-kritis } & \multirow[b]{2}{*}{ Katerangan } & \multicolumn{2}{|c|}{ Reliability Statistics } \\
\hline & & & & $\begin{array}{c}\text { Cronbach's } \\
\text { Alpha }\end{array}$ & $\mathrm{N}$ of Items \\
\hline \multicolumn{6}{|c|}{ Kecerdasan Emosional } \\
\hline P1 & 0,394 & 0,349 & Valid & \multirow{8}{*}{.573} & \multirow{8}{*}{8} \\
\hline $\mathrm{P} 2$ & 0,508 & 0,349 & Valid & & \\
\hline $\mathrm{P} 3$ & 0,366 & 0,349 & Valid & & \\
\hline P4 & 0,645 & 0,349 & Valid & & \\
\hline P5 & 0,396 & 0,349 & Valid & & \\
\hline P6 & 0,543 & 0,349 & Valid & & \\
\hline P7 & 0,536 & 0,349 & Valid & & \\
\hline P8 & 0,644 & 0,349 & Valid & & \\
\hline \multicolumn{6}{|l|}{ Kinerja } \\
\hline P1 & 0,543 & 0,349 & Valid & \multirow{10}{*}{.756} & \multirow{10}{*}{10} \\
\hline P2 & 0,564 & 0,349 & Valid & & \\
\hline P3 & 0,558 & 0,349 & Valid & & \\
\hline $\mathrm{P} 4$ & 0,735 & 0,349 & Valid & & \\
\hline P5 & 0,610 & 0,349 & Valid & & \\
\hline P6 & 0,392 & 0,349 & Valid & & \\
\hline P7 & 0,768 & 0,349 & Valid & & \\
\hline P8 & 0,638 & 0,349 & Valid & & \\
\hline P9 & 0,534 & 0,349 & Valid & & \\
\hline P10 & 0,553 & 0,349 & Valid & & \\
\hline
\end{tabular}

Sumber: Data Primer 2020

Teknik korelasi yang digunakan untuk menguji validitas butir pernyataan dalam penelitian ini adalah korelasi Pearson Product Moment. Apabila nilai koefisien korelasi butir item pernyataan yang sedang diuji lebih besar dari r-kritis 0.349. maka dapat disimpulkan bahwa item pernyataan tersebut merupakan konstruksi (construct) yang valid. kemudian dianalisis dengan menggunakan metode alpha cronbach. Kuesioner dikatakan andal apabila koefisien reliabilitas bernilai positif dan lebih besar dari pada 0.7 .

\section{Analisis Data}

Tabel 3. Hasil Analisis Uji Model Summary Model Summary

\begin{tabular}{ccccc}
\hline Model & $\mathrm{R}$ & $\mathrm{R}$ Square & Adjusted R Square & Std. Error of the Estimate \\
\hline 1 & $.055^{\mathrm{a}}$ & .003 & -.033 & 3.362 \\
\hline
\end{tabular}

a. Predictors: (Constant), $\mathrm{X}$

Sumber: data diolah tahun 2020

Tabel diatas menjelaskan besarnya nilai korelasi/hubungan $(\mathrm{R})$ yaitu sebesar 0,055 . Dari output tersebut diperoleh koefisien determinasi ( $\mathrm{R}$ Square) sebesar 0,003 , yang mengandung pengertian bahwa pengaruh variabel bebas (kecerdasan emosional) terhadap variabel terikat (kinerja karyawan) adalah sebesar 0,003 .

Tabel 4. Hasil Analisis Uji Anova

\begin{tabular}{|c|c|c|c|c|c|c|}
\hline \multicolumn{7}{|c|}{ ANOVA $^{a}$} \\
\hline & Model & Sum of Squares & $\mathrm{df}$ & Mean Square & $\mathrm{F}$ & Sig. \\
\hline & Regression & .975 & 1 & .975 & .086 & $.771^{b}$ \\
\hline 1 & Residual & 316.391 & 28 & 11.300 & .000 & \\
\hline & Total & 317.367 & 29 & & & \\
\hline
\end{tabular}

a. Dependent Variable: $Y$

b. Predictors: (Constant), $\mathrm{X}$

Sumber: data diolah tahun 2020 
Dari output tersebut diketahui bahwa nilai $\mathrm{F}$ hitung $=0,086$ dengan tingkat signifikansi sebesar $0,771>0,05$, maka model regresi dapat dipakai untuk memprediksi variabel kinerja atau dengan kata lain tidak ada pengaruh variabel kecerdasan emosional $(\mathrm{X})$ terhadap variabel kinerja karyawan (Y).

Tabel 5. Hasil Uji Regresi Coefficients $^{\mathrm{a}}$

\begin{tabular}{|c|c|c|c|c|c|c|}
\hline \multirow{2}{*}{\multicolumn{2}{|c|}{ Model }} & \multicolumn{2}{|c|}{ Unstandardized Coefficients } & \multirow{2}{*}{$\frac{\text { Standardized Coefficients }}{\text { Beta }}$} & \multirow[b]{2}{*}{$\mathrm{t}$} & \multirow[b]{2}{*}{ Sig. } \\
\hline & & B & Std. Error & & & \\
\hline & (Constant) & 43.130 & 7.186 & & 6.002 & .000 \\
\hline & $\bar{X}$ & .061 & 208 & .055 & .294 & .771 \\
\hline
\end{tabular}

a. Dependent Variable: $Y$

Sumber: data diolah tahun 2020

Diketahui nilai Constant (a) sebesar 43,130 sedangkan nilai kecerdasan emosional (b/koefisien regresi) sebesar 0,061, sehingga persamaan regresinya dapat ditulis:

$\mathrm{Y}=\mathrm{a}+\mathrm{bx}$

$\mathrm{Y}=43,130+0,061 \mathrm{x}$

Persamaan tersebut dapat diterjemahkan: Pertama, Konstanta sebesar 43,130, mengandung arti bahwa nilai konsisten variabel kinerja adalah sebesar 43,130, Kedua, koefisien regresi X sebesar 0,061 ,menyatakan bahwa setiap penembahan $1 \%$ nilai kecerdasan emosional, maka nilai kinerja bertambah sebesar 0,061 .

\section{PEMBAHASAN}

Saat ini, pekerjaan karyawan tidak hanya bergantung pada faktor intelektual mereka, tetapi juga pada kondisi emosional mereka. Orang yang dapat mengontrol emosinya dengan baik juga akan menghasilkan kinerja yang sangat baik. Hal ini sesuai dengan apa yang dikatakan Meyer (2004), bahwa EQ sama pentingnya dengan kombinasi keterampilan teknis dan analitis untuk menghasilkan kinerja yang baik.

Berdasarkan hasil penelitian diatas bahwa kecerdasan emosional tidak berpengaruh terhadap variabel terikat yaitu kinerja karyawan. Menyatakan bahwa setiap terjadi kenaikan 1 skor untuk kecerdasan emosional akan diikuti dengan kenaikan kinerja karyawan sebesar 0,061. Penelitian ini sejalan dengan penelitian yang di lakukan oleh Handayani (2019) dimana dari hasil uji regresi linear diperoleh nilai t sebesar 8.720 dengan sig. $0,000<0,05$ dan diperoleh nilai koefisien regresi sebesar 0,638 pada sig. $0,000<0,05$. Artinya setiap peningkatan sebesar I satuan kecerdasan emosional akan meningkatkan 0,683 satuan kinerja karyawan di The Axana Hotel Padang. Berbeda dengan apa yang ditemukan oleh Setyaningrum et al., (2016) bahwa kesadaran diri, pengaturan diri, motivasi, empati dan keterampilan sosial memiliki pengaruh signifikan secara parsial maupun simultan terhadap variabel kinerja karyawan.

Berdasarkan hasil uji t yang menunjukkan bahwa "kecerdasan emosional tidak berpengaruh signifikan terhadap kinerja karyawan" maka dapat disimpulkan bahwa hipotesis tidak diterima. Hal ini disebabkan karena karyawan Bank Mandiri Cabang Bone merasa yakin bahwa mereka memiliki kinerja yang baik. Berbeda dengan penelitian Putri, (2016) bahwa pengaruh kecerdasan emosional terhadap kinerja dengan uji $t$ yaitu hasil yang diperoleh $t_{\text {hitung }}(4.167)>t_{\text {tabel }}(1,996)$ dengan taraf signifikasi 0,05 maka Ho ditolak sehingga ada pengaruh yang signifikan kecerdasan emosional terhadap kinerja karyawan. Jika dilihat dari pola hubungannya, maka kecerdasan emosional memberikan pengaruh positif terhadap kinerja. Artinya semakin baik kecerdasan emosional, maka kinerja semakin baik. Baiknya kecerdasan emosional dapat memberikan pengaruh terhadap kinerja karyawan.

Sedangkan Nirwana (2021) dalam penelitiannya tentang pengaruh kecerdasan emosional, etos kerja Islami dan motivasi kerja terhadap kinerja karyawan konveksi yang di moderasi oleh religiusitas menemukan bahwa kecerdasan emosional berpengaruh positif dan tidak signifikan terhadap kinerja karyawan konveksi. Begitupula dengan penelitian yang di lakukan oleh Nursavilla \& Sri Padmantyo, (2020) dalam penelitiannya Pengaruh Kecerdasan Emosional dan Stres Kerja Terhadap Kinerja Karyawan (Studi Pada Unit Spinning 2 PT. Dan Liris di Sukoharjo) menemukan bahwa kecerdasan emosional berpengaruh positif dan signifikan terhadap kinerja karyawan.

Berdasarkan berbagai sudut pandang di atas, terlihat bahwa kecerdasan emosional termasuk dalam aspek pekerjaan yang sangat penting. Kemampuan untuk memotivasi diri sendiri, Kendalikan emosi, kenali emosi orang lain, atasi frustasi, atur emosi dan faktor penting lainnya. Jika setiap 
karyawan dapat memahami aspek-aspek ini dengan benar di tempat kerja, itu akan membantu mencapai kinerja yang baik. Maka dapat diketahui dengan jelas bahwa kecerdasan emosional tidak berpengaruh terhadap kinerja karyawan.

Penjelasan yang dapat diberikan dari hasil analisis ini menunjukkan bahwa hasil koesioner saya tidak valid dikarenakan dalam bekerja tidak boleh menyangkut pautkan dengan urusan keluarga dan pekerjaan atau masalah apapun itu karena dalam bekerja harus fokus dalam suatu pekerjaan. Hasil penelitian ini mengimplementasikan bagi perusahaan, bank dan lain-lain bahwa individu yang memiliki kecerdasan untuk mengatur emosionalnya akan menghasilkan kinerja yang baik.

\section{KESIMPULAN}

Dalam hasil penelitian diatas mengenai pengaruh kecerdasan emosional terhadap kinerja maka sebagai penulis dapat menyimpulkan bahwa pengaruh kecerdasan emosional tidak berpengaruh terhadap kinerja karyawan pada Bank Mandiri cabang Bone. Hal ini disebabkan karena karyawan Bank Mandiri Cabang Bone merasa yakin bahwa mereka memiliki kinerja yang baik.

Secara Praktis peneliti menyarankan agar karyawan tenang dalam menjalankan setiap aktivitasnya agar tidak membuat orang lain emosi, tidak mudah tenggelam dan berlarut - larut. agar pekerjaannya bisa terselesaikan sesuai dengan apa yang diinginkan dan hendaknya pihak perusahaan memperhatikan kondisi karyawan dalam situasi apapun. Hal ini dilakukan agar kondisi emosi karyawan bisa stabil dalam menjalankan aktivitasnya, dan secara Teoritis peneliti menyarankan bagi peneliti selanjutnya agar dapat melakukan penelitian lebih mendalam terhadap kinerja karyawan dengan melihat dari berbagai faktor-faktor yang mempengaruhinya seperti kompensasi, lingkungan kerja, budaya organisasi, kepemimpinan, motivasi kerja, disiplin kerja, kepuasan kerja dan komunikasi.

\section{REFERENSI}

Armansyah, A. (2018). Penerapan Sistem Pembinaan Halaqah Untuk Meningkatkan Kecerdasan Emosional. TAJDID: Jurnal Pemikiran Keislaman Dan Kemanusiaan, 2(1), 341-354.

Casmini, M. (2007). Pendidikan Segregasi. Bandung: Universitas Pendidikan Indonesia.

Dina, N. (2008). Manajemen Sumber Daya Manusia, Dasar dan Kunci Keberhasilan. Jakarta: Haji Masagung.

Fachrur, M. (2019). Pengaruh Kecerdasan Emosional dan Kecerdasan Spiritual Terhadap Kinerja Karyawan Pada RSUD Bendan Kota Pekalongan. PPMA FE Universitas Pekalongan.

Gaffar, A. (2020). The Development of Islamic Thought on Multiple Perspectives. 11.

Goleman, D. (2004). Primal Leadership: Kepemimpinan Berdasarkan Kecerdasan Emosi. Jakarta: Gramedia Pustaka Utama.

Goleman, D., Boyatzis, R., \& McKee, A. (2002). The Emotional Reality of Teams. Journal of Organizational Excellence, 21(2), 55-65.

Handayani, F. (2019). Pengaruh Kecerdasan Emosional Terhadap Kinerja Karyaw an di The Axana Hotel Padang. Universitas Negeri Padang.

Hariyoga, S., \& Suprianto, E. (2011). Pengaruh Kecerdasan Emosional, Perilaku Belajar, dan Budaya terhadap Tingkat Pemahaman Akuntansi dengan Kepercayaan Diri sebagai Variabel Pemoderasi. Simposium Nasional Akuntansi XIV.

Hasibuan, M. (2006). Manajemen Dasar, Pengertian, dan Masalah (Edisi Revi). Jakarta: Bumi Aksara. Hasibuan, M. (2016). Manajemen Sumber Daya Manusia. Jakarta: Bumi Aksara.

Khumaedi, E. (2016). Pengaruh Disiplin dan Motivasi Kerja terhadap Kinerja Pegawai pada Dinas Sentra Operasi Terminal PT. Angkasa Pura II. Jurnal Ilmiah Manajemen Dan Bisnis Mercu Buana, 2(1), 96749.

Koontz, M. (1997). Manajemen Tenaga Kerja dan Hubungan Kerja. Bandung: CV. Pionir Jaya.

Lantieri, L., Goleman, D., \& Bannel, E. P. (2009). Inteligencia Emocional Infantil Y Juvenil: Ejercicios Para Cultivar la Fortaleza Interior en Niños Y Jóvenes.

Mangkunegara, A. A. A. P. (2016). Manajemen Sumber Daya Manusia Perusahaan. Bandung: Remaja Rosdakarya. 
Mangkunegara, A. P. (2002). Manajemen Sumber Daya Manusia Perusahaan (Cetakan 2). Bandung: PT. Remaja Rosdakarya Offset.

Mangkuprawira, S. (2011). Manajemen Sumber Daya Manusia Strategik (2nd ed.). Bogor: Ghali Indonesia.

Manuaba, A. (2004). Hubungan Beban Kerja Dan Kapasitas Kerja. Jakarta: Rineka Cipta.

Meyer, J. (2004). EQ dan Kesuksesan Kerja. http:// www. e-psikologi. com.

Nawawi, H. (2006). Evaluasi dan Manajemen Kinerja di Lingkungan Perusahaan dan Industri. Yogyakarta: Gadjah Mada University Press.

Nirwana, M. T. (2021). Pengaruh Kecerdasan Emosional, Etos Kerja Islami dan Motivasi Kerja terhadap Kinerja Karyawan Konveksi yang di Moderasi oleh Religiusitas. IAIN Salatiga.

Nursavilla, F., \& Sri Padmantyo, M. B. A. (2020). Pengaruh Kecerdasan Emosional dan Stres Kerja Terhadap Kinerja Karyawan (Studi Pada Unit Spinning 2 PT. Dan Liris di Sukoharjo). Universitas Muhammadiyah Surakarta.

Permendagri. Peraturan Menteri Dalam Negeri Nomor 12 Tahun 2008 Tentang Pedoman Analisis Beban Kerja di Lingkungan Departemen Dalam Negeri dan Pemerintah Daerah. , (2008).

Prawirosentono, S. (2008). Manajemen Sumber Daya Manusia Kebijakan Kinerja Karyawan Kiat Membangun Organisasi Kompetitif Era Perdagangan Bebas Dunia. Yogyakarta: BPFE.

Purnomo, R. A. (2016). Ekonomi Kreatif Pilar Pembangunan Indonesia. Surakarta: Ziyad Visi Media.

Putra, A. S. (2012). Analisis Pengaruh Beban Kerja Terhadap Kinerja Karyawan Divisi Marketing dan Kredit PT. WOM Finance Cabang Depok. Jurnal Studi Manajemen Indonesia, 12.

Putri, Y. S. (2016). Pengaruh Kecerdasan Intelektual, Kecerdasan Emosional, dan Lingkungan Kerja terhadap Kinerja Karyawan PT. PLN Persero Area Llaten. Jurnal Studi Manajemen Organisasi, 13(1), 88-97.

Ryza, P. (2018). Pemimpin dan Bagaimana Seharusnya Memberikan Umpan Balik. Retrieved April 20, 2021, from https://dailysocial.id website: https://dailysocial.id/post/pemimpin-dan-bagaimanaseharusnya-memberikan-umpan-balik

Setyaningrum, R., Utami, H. N., \& Ruhana, I. (2016). Pengaruh Kecerdasan Emosional Terhadap Kinerja (Studi Pada Karyawan PT. Jasa Raharja Cabang Jawa Timur). Jurnal Administrasi Bisnis, 36(1), 211-220.

Sugiyono. (2015). Metode Penelitian Kombinasi (Mixed Methods). Bandung: Alfabeta.

Tampi, B. J. (2014). Pengaruh Gaya Kepemimpinan dan Motivasi terhadap Kinerja Karyawan pada PT. Bank Negara Indonesia, tbk (Regional Sales Manado). Acta Diurna Komunikasi, 3(4), 1-20.

Wibowo, B. S. (2002). Sharpehing Our Concept And Tools. Bandung: PT Syamil Cipta Media.

Wibowo, S. (2010). Manajemen Kinerja (3rd ed.). Jakarta: Raja Grafindo Persada. 